\title{
Perfil de sensibilidade de enterobactérias isoladas de abcessos pós-vacinais presentes em carcaças de bovinos abatidos em frigoríficos
}

Rogerio Giuffrida", Tauane de Oliveira Felix, Maiara Aparecida de Almeida, Franklin Leandro, Juliana Pampana Nicolau

Universidade do Oeste Paulista (UNOESTE), Presidente Prudente, SP, Brasil

*Autor correspondente

e-mail: rgiuffrida@unoeste.br

\section{Resumo}

Abcessos pós-vacinais no ponto de injeção são complicações comuns em bovinos no Brasil. Estas afecções decorrem geralmente da higiene deficiente no procedimento de vacinação, associada à ação irritante dos adjuvantes vacinais, gerando prejuízos em razão da condenação das porções afetadas nos frigoríficos. 0 presente estudo avaliou o perfil de sensibilidade microbiana de enterobactérias isoladas de abcessos pósvacinais de bovinos abatidos. Foram avaliados 100 abcessos de 100 bovinos, distribuídos em 10 lotes, abatidos em frigorifico do município de Pirapozinho/SP. Durante o abate, porções da musculatura condenadas em razão da presença de lesões purulentas, foram assepticamente removidas das carcaças e transportadas sob refrigeração para o laboratório de análises microbiológicas. As amostras de pus foram semeadas em ágar sangue ovino desfibrinado e ágar Mac Conkey. Após 24-48 horas de incubação a $37^{\circ} \mathrm{C}$, colônias bacterianas isoladas foram classificadas segundo características morfotintoriais e bioquímicas, incluindo acidificação da glicose, sacarose e ramnose, produção de gás sulfídrico e indol, motilidade em meio semissólido, descarboxilação da lisina, ornitina e triptofano e uso de carbono como fonte energia. A classificação final foi obtida por métodos probabilísticos. Verificou-se que 28 (28\%) dos 100 abcessos avaliados resultaram em isolamento de Gram-negativos, dos quais 20 foram caracterizados como enterobactérias. Dos 10 lotes avaliados, $6(60 \%)$ foram positivos para enterobactérias. Foram isoladas as seguintes espécies: Klebsiella oxytoca $(\mathrm{N}=1)$, Serratia liquefaciens $(\mathrm{N}=1)$, Citrobacter freundii $(\mathrm{N}=2)$, Citrobacter $\operatorname{spp}(\mathrm{N}=2)$, Complexo Enterobacter $\operatorname{spp}(\mathrm{N}=2)$, Enterobacter aggllomerans $(\mathrm{N}=5)$ e Escherichia coli $(\mathrm{N}=7)$. Os isolados foram submetidos ao teste de disco-difusão em agar Müller-Hinton para determinação de sensibilidade microbiana, sendo verificados os seguintes percentuais de sensibilidade: Ampicilina $(9 / 20=45 \%)$, Bacitracina de zinco $(1 / 20=5 \%)$, Ciprofloxacina $(18 / 20=90 \%)$, Ceftiofur $(16 / 20=80 \%)$, Enrofloxacina $(16 / 20=80 \%)$, 
Eritromicina (1/20 = 5\%), Gentamicina (20/20 = 100\%), Sulfametoxazol + Trimetopriim $(20 / 20=100 \%)$, Tetraciclina $(19 / 20=95 \%)$ e Virgniamicina $(2 / 20=10 \%)$. Não foram observados agentes multirresistentes (resistentes a três ou mais classes de antimicrobianos). 0 perfil de microrganismos isolados evidencia deficiências nas práticas de higiene adotadas nos procedimentos de vacinação, visto que enterobactérias são microrganismos fecais capazes de colonizar transitoriamente a pele dos bovinos, sendo introduzidos na musculatura durante a vacinação. De acordo com o perfil de sensibilidade, antimicrobianos de uso metafilático (Bacitracina de zinco, Eritromicina e Viginiamicina) apresentaram baixa atividade frente aos isolados, não sendo recomendados para prevenir estas afecções. Em contraste, antimicrobianos de uso terapêutico apresentaram boa atividade frente aos isolados, com exceção da Ampicilina, podendo ser recomendados para o tratamento de casos complicados, desde que se respeite o período de carência para o abate. Conclui-se que a prevenção da ocorrência de abcessos pós-vacinais deve ser baseada na adoção de boas práticas de vacinação. 